\title{
The Study on the Whole Stress-Strain Curves of Coral Fly Ash-Slag Alkali-Activated Concrete under Uniaxial Compression
}

\author{
Huailiang Wang ${ }^{1,2}$, Lang Wang ${ }^{1}$, Lei Li $^{3}$, Baoquan Cheng ${ }^{4, *}$, Yonggang Zhang ${ }^{5}$ and \\ Yuhu Wei ${ }^{6}$ \\ 1 College of Civil Engineering and Architecture, Guangxi University, Nanning 530004, China; \\ Whuailiang@gxu.edu.cn (H.W.); wanglang@st.gxu.edu.cn (L.W.) \\ 2 Key Laboratory of Disaster Prevention and Structural Safety of Ministry of Education, \\ Nanning 530004, China \\ 3 School of civil engineering, Xi'an University of Architecture and Technology, Xi'an 710055, China; \\ lilei@xauat.edu.cn \\ 4 School of Civil Engineering, Central South University, Changsha 410083, China \\ 5 Key Laboratory of Geotechnical and Underground Engineering of Ministry of Education, \\ Department of Geotechnical Engineering, Tongji University, Shanghai 200092, China; \\ demonzhangyg@tongji.edu.cn \\ 6 College of Civil Engineering, Anhui Jianzhu University, Hefei 230000, China; aarondamen@163.com \\ * Correspondence: 18096562g@connect.polyu.hk
}

Received: 2 September 2020; Accepted: 23 September 2020; Published: 25 September 2020

\begin{abstract}
This study aimed to research the whole stress-strain curves of coral Fly Ash-Slag Alkali-Activated Concrete (CAAC) in different strength grades. Fly ash-slag alkali-activated concrete was used as cementing materials to produce coral aggregate concrete. A monotonic loading test was conducted on the prismatic specimens to obtain elastic modulus $\left(E_{\mathrm{C}}\right)$, Poisson's ratio $(\mu)$ and the constitutive relationship of CAAC under uniaxial compression. When the strain of CAAC reached the maximum value, the specimen was split and damaged rapidly. As the strength grade increased, the ratio of residual stress $\left(\sigma_{\mathrm{ri}}\right)$ to peak stress $\left(\sigma_{0 \mathrm{i}}\right)$ decreased in the range of $0.17-0.28$. The $E_{\mathrm{c}}$ of CAAC increased gradually, and $\mu$ increased to the peak value and then decreased. According to the test results, the constitutive equation of CAAC can be expressed by piecewise expression, which can better reflect all the experimental characteristics. It was also found that CAAC has many similar characteristics with coral concrete and lightweight aggregate concrete. To improve the strength and toughness of CAAC, some fibers, such as organic fiber, can be added to expand the application of $\mathrm{CAAC}$ in engineering projects.
\end{abstract}

Keywords: coral aggregates; fly ash-slag alkali-activated concrete; monotonic loading method; whole stress-strain curve; elastic modulus; Poisson's ratio

\section{Introduction}

In recent years, with the rapid development of urban construction, the amount of cement used worldwide has surged. At the end of the last century, the global cement consumption exceeded 2.2 billion tons per year [1]. According to Elchalakani [2], the production of ordinary Portland cement reached 3.7 billion tons in 2017, which was accompanied by 3 billion tons of $\mathrm{CO}_{2}$ emissions, accounting for about $7 \%$ of the total global emissions. Statistics released by the European Cement Association [3] showed that the cement output of the European Union was about 170 million tons in 2016, making it one of the major cement producers in the world. In 2016, China produced more than half of the world's 
cement, exceeding 2.4 billion tons. From 2015 to 2016, Australia's cement output was nearly 10 million tons, up 5\% year on year [4]. Hao et al. [5] and Cheng et al. [6] also reported that concrete is one of the most important sources of environmental impacts caused by construction activities.

The environmental problems caused by cement production in the world cannot be ignored [7].

According to the report, during cement production [8], every ton of cement can generate about 1 ton of carbon dioxide emissions, and more than $1 / 20$ of the global carbon dioxide emissions are related to cement production [9]. Therefore, many researchers have been working to develop an alternative to ordinary Portland cement construction material in recent years.

At the same time, with the rapid development of urbanization, many high-rise buildings, highways, factories, etc. have been built, which requires a large amount of concrete [10]. Because of its low cost and long durability, concrete has become the most commonly used building material, with an annual consumption of about 30 billion tons [11]. However, the raw materials used to make concrete will lead to large amount of carbon emissions during the manufacturing, which will cause pollution to the environment $[12,13]$. In addition, the production of a large amount of concrete requires a lot of sand, stone, water and other raw materials; the large consumption of these raw materials will cause severe damage to the land, water resources and air quality. In other words, the environmental quality will be greatly affected. Therefore, a new type of concrete, with both economic and ecological benefits, is badly needed [14-22].

The emergence of geopolymer [23] is expected to highly reduce the impact of construction activities on the environment. Geopolymer is made from industrial wastes and contains no cement. Compared with ordinary concrete (OPC), the same amount of geopolymer concrete (GC) can be produced with $40 \%$ of the energy required, while $\mathrm{CO}_{2}$ emissions are reduced by $80 \%$ [24-27]. At present, there have been many studies on GC and alkali activated slag concrete (AASC). According to the existing research results, compared with traditional OPC, alkali-activated concrete (AAC) has similar or better performance in terms of early-age strength [28], fire resistance [29], thermal stability [30], water absorption, permeability [31,32], chloride resistance [33,34] and durability [35]. Previous studies on geopolymers mainly focused on the microstructure, but there were few studies on the practical application of geopolymers in structural members or structures [36-42]. Recently, some scholars have done some research on the mechanical properties of geopolymer concrete [43] and the properties of alkali-activated lightweight aggregate concrete [44]. Zbigniew et al. [45] studied the effect of geopolymer cementitious material fly ash and slag on the mechanical properties of concrete. Fabio et al. [46] studied the properties of fiber-reinforced geopolymer mortar. Wang et al. [47] investigated the performance of actively confined geopolymer concrete. Some scholars $[48,49]$ had studied the influence of the variability of calcareous fly ash properties on the rheological properties of fresh mortar and the influence of nano-silica on the chemical durability and mechanical properties of fly ash-based geopolymer concrete.

Due to the exhaustion of land resources, the development of ocean is of great strategic significance. Construction materials and freshwater resources on an island are extremely limited, and construction on an island is limited by high upfront cost. Therefore, it is logical to use local coral aggregates to take the place of traditional building materials. Coral aggregates concrete is prepared using coral aggregates instead of natural sandstone, thus posing no damage to the natural ecological environment on the island. There are many coral reefs in the sea by islands, with major components of aragonite. The high magnesium calcite is a special type of rock-soil with a $\mathrm{CaCO}_{3}$ content of more than $96 \%$. These reefs can be made into coral aggregates, providing a new engineering material for the construction of islands [50,51].

At present, research on coral concrete (CPC) mainly focuses on the mix design, durability and basic mechanical properties. In 1951, Dempsey [52] pointed out that, if the CPC were of high quality and density, it would suffer little corrosion, but it might be corroded after long-time exposure in a humid environment. In 1982, Vines [53] found that the strength structure and durability of local CPC were poor in Samoa, South Pacific. In 1989, Zhaolin [54,55] systematically studied the basic mechanical 
properties of CPC by preparing different types of CPC specimens. In 2012, Lei [56] found that CPC and lightweight aggregate concrete (LPC) have similar characteristics in strength development, failure mechanism and failure performance. In 2013, Yingtao [57] studied CPC and OPC with the same mix ratio and the performance differences in frost resistance and corrosion resistance. They found that fly ash or slag can be added to CPC to improve its freezing and corrosion resistance. The above research provides important reference for the application of CPC.

The combination of geopolymer binders and coral aggregates reduces the consumption of sand and cement and achieves eco-friendly concrete production. The whole stress-strain curve of uniaxial compression is the basis for studying the bearing capacity and deformation of concrete structures [58]. For the whole stress-strain curves of CPC and LPC, there have been some research results [59-61]. However, the whole stress-strain curve of CAAC that uses coral instead of ordinary aggregate has not been studied in detail.

In this study, fly ash-slag and coral aggregates were combined to prepare alkali-activated coral aggregates concrete with three strength grades. From the perspective of structural design, the whole stress-strain curve of CAAC was systematically studied and compared with normal weight alkali-activated concrete (NAAC) with limestone aggregates, CPC and LPC of the same strength grades. It is of great significance to provide basic constitutive relation for the application of CAAC.

\section{Experimental Program}

\subsection{Materials}

The binder materials used in this study were fly ash (FA) and ground granulated blast furnace slag (GGBFS), which obtained from China Resources mixing Station, Nanning, China. The chemical compositions and physical properties of the FA and GGBFS are listed in Table 1. Two types of coarse aggregates were used in this research project: coral aggregates (Figure 1) and limestone aggregates (Qinzhou, China). Limestone with a maximum size of $20 \mathrm{~mm}$ and aggregate crushing value of $23 \%$ was employed as coarse aggregates for NAAC. The coral comes from some islands and reefs in Beihai City, Guangxi Zhuang Autonomous Region, China. The coral with a maximum size of $20 \mathrm{~mm}$ (Figure 2b), cylinder compressive strength of $2.12 \mathrm{MPa}$ and $24 \mathrm{~h}$ water absorption ratio of $14.2 \%$ was used as coarse aggregates for CAAC. Natural river sand (Figure 2a) with fineness modulus of 2.4 was used as fine aggregates for all concrete mixtures. The fineness modulus, specific gravity, water absorption, aggregates crushing value and cylinder compressive strength of different aggregates were determined according to Chinese National Standard GB/T 17431-1998 [62], as listed in Table 2.

Table 1. Properties and compositions of the pozzolanic materials.

\begin{tabular}{|c|c|c|c|c|c|c|c|c|}
\hline \multirow{2}{*}{ Sample } & \multicolumn{5}{|c|}{ Chemical Composition (\%) } & \multirow{2}{*}{$\begin{array}{l}\text { Blaine Fineness } \\
\left(\mathrm{cm}^{2} / \mathrm{g}\right)\end{array}$} & \multirow{2}{*}{$\begin{array}{l}\text { Density } \\
\left(\mathrm{g} / \mathrm{cm}^{3}\right)\end{array}$} & \multirow{2}{*}{$\begin{array}{l}\text { LOI } \\
(\%)\end{array}$} \\
\hline & $\mathrm{SiO}_{2}$ & $\mathrm{Al}_{2} \mathrm{O}_{3}$ & $\mathrm{CaO}$ & $\mathrm{Fe}_{2} \mathrm{O}_{3}$ & $\mathrm{MgO}$ & & & \\
\hline FA & 49.10 & 26.70 & 6.96 & 9.67 & 1.37 & 3871 & 2.21 & 2.08 \\
\hline GGBFS & 32.28 & 13.80 & 47.85 & 0.74 & 3.73 & 3862 & 2.86 & 1.30 \\
\hline
\end{tabular}

Table 2. Physical properties of coarse and fine aggregates.

\begin{tabular}{ccccccc}
\hline Aggregates & $\begin{array}{c}\text { Particle Size } \\
(\mathbf{m m})\end{array}$ & $\begin{array}{c}\text { Specific } \\
\text { Gravity }\end{array}$ & $\begin{array}{c}\text { 24-h Water } \\
\text { Absorption (\%) }\end{array}$ & $\begin{array}{c}\text { Fineness } \\
\text { Modulus }\end{array}$ & $\begin{array}{c}\text { Aggregates } \\
\text { Crushing } \\
\text { Value (\%) }\end{array}$ & $\begin{array}{c}\text { Cylinder } \\
\text { Compressive } \\
\text { Strength (MPa) }\end{array}$ \\
\hline $\begin{array}{c}\text { Natural river sand } \\
\text { Limestone }\end{array}$ & $\leq 5$ & 2.67 & 1.2 & 2.4 & - & - \\
$\begin{array}{c}\text { aggregates } \\
\text { Coral aggregates }\end{array}$ & $5-20$ & 2.64 & 0.83 & - & 23 & - \\
\hline
\end{tabular}




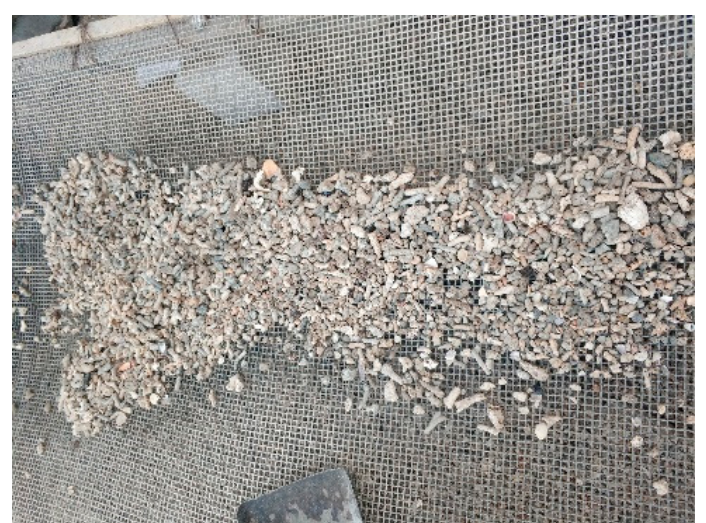

(a)

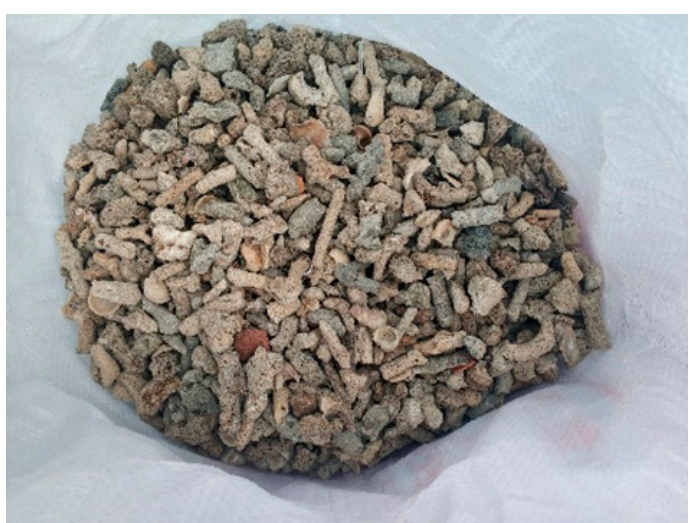

(b)

Figure 1. Coral aggregates for test: (a) broken coral; and (b) coral aggregates.

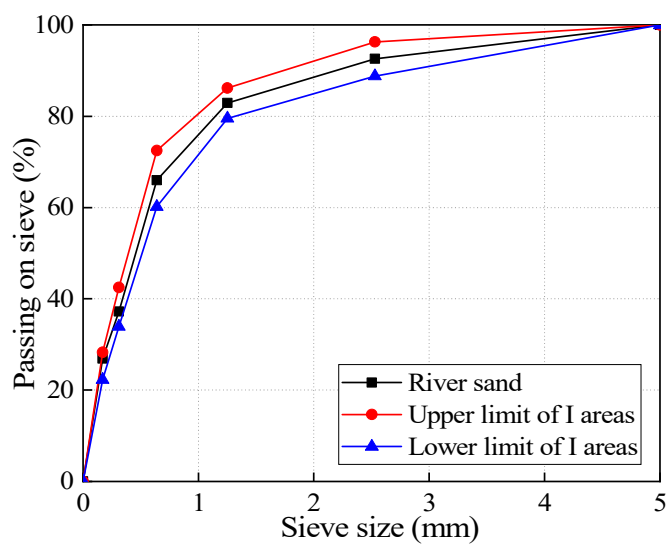

(a)

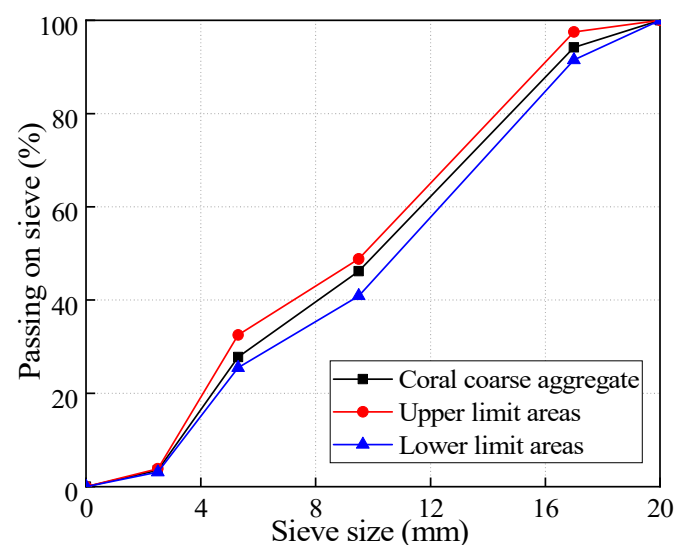

(b)

Figure 2. Size distribution of river sand and coral aggregates: (a) fine aggregates; and (b) coarse aggregates.

\subsection{Mixture Proportions and Specimen Preparation}

The alkali activator used in this study is a mixture of $\mathrm{NaOH}$ solid and sodium silicate (SS) solution. For all AAC mixtures and mixtures containing additional water, the ratio of sodium silicate solution to $\mathrm{NaOH}$ was constant at 2.5. The chemical composition of SS solution was $\mathrm{Na}_{2} \mathrm{O}=13.6 \%$, $\mathrm{SiO}_{2}=29.9 \%$ and $\mathrm{H}_{2} \mathrm{O}=56.5 \%$ by mass. The specific gravity and the modulus of SS solution were 1.35 and 3.0, respectively. The solution of alkali activator was prepared by dissolving $\mathrm{NaOH}$ pellets with $99 \%$ purity in sodium silicate solution for $24 \mathrm{~h}$. Potable tap water was used in all concrete mixes, and poly-carboxylic type superplasticizer (SP) with a specific gravity of 1.18 and $\mathrm{pH} 7$ was used in NAAC and CAAC mixtures.

The term water/solid (W/S) ratio in AAC was defined as the ratio of the total mass of water in the mixture to the sum of the mass of blended FA-GGBFS powder material, $\mathrm{NaOH}$ solids and sodium silicate solids. The W/S ratio determines the strength of AAC. In this experiment, the slump value of the designed AAC was 15-22 cm. Therefore, the dosage of superplasticizer for each mixture with different $W / S$ ratio was modified to achieve the specified slump value.

In addition, the minimum target compressive strength of CAAC should exceed $20 \mathrm{MPa}$ for application to structural concrete members. In 2013, Vora et al. [63] found that the compressive strength of alkali-activated concrete decreased with the increase of water-binder ratio. Alkali activated concrete is composed of coarse aggregate, fly ash, ground granulated blast furnace slag, sodium silicate, $\mathrm{NaOH}$, river sand, water and superplasticizer. According to the research of Yinfeng et al. [64] and a series 
of trial matches, three different strength grades of alkali-activated concrete were designed. The mix proportions are shown in Table 3.

Table 3. Mixture proportions of AACs $\left(\mathrm{kg} / \mathrm{m}^{3}\right)$.

\begin{tabular}{ccccccccccc}
\hline Mix ID & FA & GGBFS & $\begin{array}{c}\text { Sodium } \\
\text { Silicate }\end{array}$ & NaOH & $\begin{array}{c}\text { River } \\
\text { Sand }\end{array}$ & $\begin{array}{c}\text { Normal Weight } \\
\text { Aggregates }\end{array}$ & $\begin{array}{c}\text { Coral } \\
\text { Aggregates }\end{array}$ & $\begin{array}{c}\text { Added Water } \\
\text { W/S }\end{array}$ & Superplasticizer \\
\hline NAAC-C30 & 210 & 140 & 110 & 44 & 773 & 1094 & - & 23.1 & 0.29 & 0.9 \\
NAAC-C40 & 234 & 156 & 122 & 49 & 764 & 1023 & - & 11.5 & 0.25 & 1.4 \\
NAAC-C50 & 298 & 199 & 131 & 52 & 705 & 958 & - & 5.9 & 0.21 & 2.8 \\
CAAC-C30 & 216 & 144 & 110 & 44 & 868 & - & 605 & 13.1 & 0.26 & 2.1 \\
CAAC-C40 & 266 & 177 & 122 & 49 & 844 & - & 531 & 8.3 & 0.22 & 3.3 \\
CAAC-C50 & 339 & 226 & 124 & 50 & 790 & - & 462 & 5.5 & 0.18 & 4.8 \\
\hline
\end{tabular}

At present, there is no standard available as a reference for the mixing procedure of AAC, especially for structural-grade lightweight AAC. In this study, FA, GGBFS and aggregates were first stirred in a drum mixer for 5 min when NAAC was made. Then, the alkali activator solution and the mixture of water and superplasticizer were gradually added to the mixer, and the stirring process lasted another $5 \mathrm{~min}$. Before the preparation of CAAC, it was necessary to soak the coral aggregate in tap water to remove impurities and reduce the concentration of chloride ion and then dry them. During the preparation, the coral aggregates were firstly wetted with little sodium silicate solution and stirred for $2 \mathrm{~min}$, and then FA, GGBFS and river sand were added and stirred for $2 \mathrm{~min}$. Finally, the alkali activator solution, superplasticizer and water were added gradually and stirred for $5 \mathrm{~min}$. All the AAC concretes were put into the steel model and vibrated on the shaking table for about 10-20 s. It is noted that sodium silicate solution treatment of coral aggregates in the casting procedure of AAC can help to improve the quality of coral aggregates particle by reducing water absorption and increasing strength.

For each strength grade mixture, three $100 \mathrm{~mm} \times 100 \mathrm{~mm} \times 100 \mathrm{~mm}$ cubes and three $100 \mathrm{~mm} \times$ $100 \mathrm{~mm} \times 300 \mathrm{~mm}$ prisms were cast. After casting, all specimens were covered with plastic film to prevent water loss. The specimens were taken out of the mold after $24 \mathrm{~h}$ and placed in a curing room at $25 \pm 5{ }^{\circ} \mathrm{C}$ and relative humidity of $50-55 \%$ for 30 days.

\subsection{Test Methods}

In this study, the uniaxial compression tests were performed on RMT-201 rock and concrete mechanical test system at the Structural Laboratory of Guangxi University, Nanning, China. The maximum loading range of the testing machine was $1500 \mathrm{kN}$, with an accuracy of $0.001 \mathrm{kN}$, and the minimum loading rate was $0.001 \mathrm{~mm} / \mathrm{s}$. According to the Chinese National Standard GB/T 50081-2002 [65], the compressive stress-strain relationship test was carried out on prism specimens with size of $100 \mathrm{~mm} \times 100 \mathrm{~mm} \times 300 \mathrm{~mm}$; at the same time, elastic modulus and Poisson's ratio of different concrete mixtures could be estimated. The instruments used in the test were displacement transducers and recorders [66]. The load, displacement and strain were collected by corresponding data acquisition system and stored in computer during the experiment process.

The test equipment and the schematic diagram of the loading device are shown in Figure 3. The displacement-controlled loading mode was adopted with a loading speed of $0.002 \mathrm{~mm} / \mathrm{s}$. A linear variable differential transformer with a measurement range of $\pm 5 \mathrm{~mm}$ and precision of $400 \mu \varepsilon / \mathrm{mm}$ was used to measure the axial (vertical) displacement and the lateral displacement. At the same time, to improve the accuracy of the measurement and reduce the influence of the end of the specimen and the supporting plate on the test results, the axial and lateral strains of the AACs were also measured by the strain gauges. The horizontal strain gauge was used to measure the transverse strain, while the vertical strain gauge was not only used to measure the longitudinal strain but also used to check whether the specimen was flat. Load was measured with a load sensor mounted on the top of the specimen. The load, strains, axial and lateral deformation of specimens were collected and recorded by the Donghua-DH3818Y static strain testing system (Liyang, China), and 100 data points were recorded per second. According to the cube compressive strength obtained before this study, the peak load was 
estimated, and the specimens were preloaded once before formal loading with $10-20 \%$ of the peak load. After formal loading, it terminated when the load dropped to $15 \%$ of the peak load $[67,68]$.

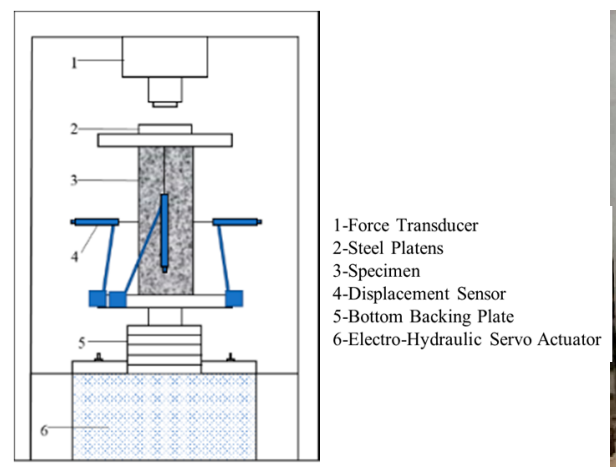

(a)

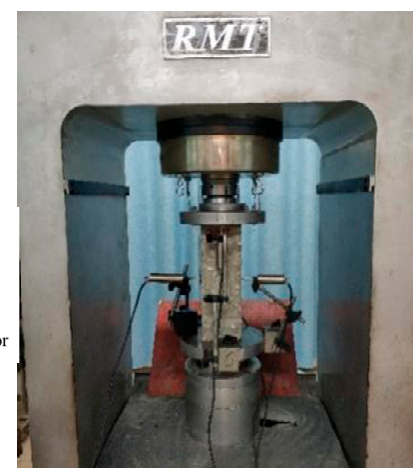

(b)

Figure 3. Test set-up: (a) schematic of setup for loading; and (b) test equipment.

The axial deformation in this study is the average value of the vertical LVDT and the axial strain gauges.

The complete failure process of the specimen can be seen in the loading process. During the test, it is necessary to observe and record the form and development of the crack and the shedding phenomenon on the surface of the specimen. During the loading process, the strain gauge will be damaged when the crack penetrates, so the strain gauge generally measures the data before the specimen cracks.

\subsection{Elastic Modulus and Poisson's Ratio}

According to the American Society for Testing Materials (ASTM) [69], the elastic modulus calculation formula is as follows:

$$
E_{c}=\frac{\sigma_{2}-\sigma_{1}}{\varepsilon_{2}-\varepsilon_{1}}
$$

where $\varepsilon_{1}$ is the axial strain $(0.0005) ; \sigma_{1}$ is the major principal stress; $\varepsilon_{2}$ is the longitudinal strain; and $\sigma_{2}$ is the stress corresponding to $40 \%$ of peak load.

The Poisson's ratio, $\mu$, was calculated as follows:

$$
\mu=\frac{\varepsilon_{t 2}-\varepsilon_{t 1}}{\varepsilon_{2}-\varepsilon_{1}}
$$

where $\varepsilon_{t 1}$ and $\varepsilon_{t 2}$ are the transverse strains corresponding to $\varepsilon_{1}$ and $\varepsilon_{2}$, respectively.

\section{Test Results and Discussion}

\subsection{Compressive Failure Mode}

The whole experimental process has three parts: (1) When the force on the specimen reached 0.10-0.20 times the peak load, the peeling phenomenon of CAAC occurred, which indicated that the specimen was in the compaction stage. (2) When the force on the specimen reached 0.6-0.85 times the peak load, small longitudinal cracks appeared on the surface of the specimen. Most cracks developed slowly and steadily. (3) When the loading continued, the crack continued to develop and extend to both ends of the specimen, and eventually led to the failure of the specimen. This indicates that the crack at this stage is not in stable development. These phenomena showed that CAAC was very brittle. With the increase of CAAC strength grade, the damage pattern was more serious and unpredictable. The failure characteristics of the NAAC and CAAC specimens were found to be similar, both with diagonal shear failure. The typical failure patterns are illustrated in Figure 4. For different strength grades of AACs, the failure modes were very similar. 


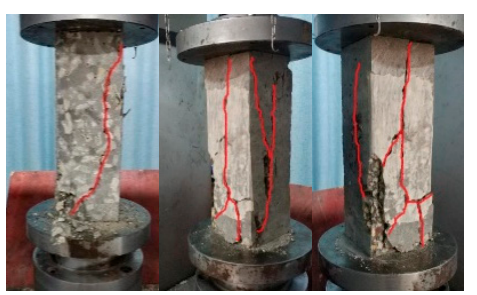

(a)

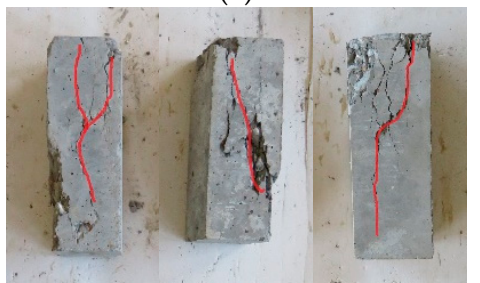

(d)

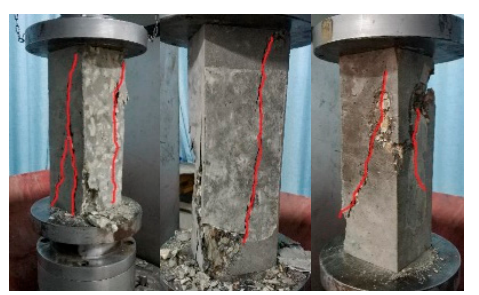

(b)

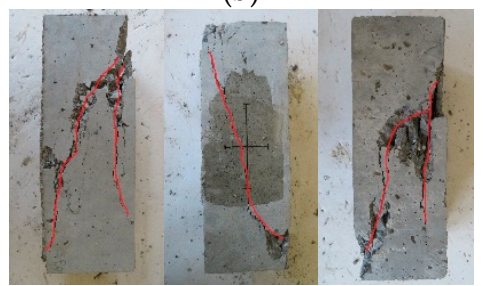

(e)

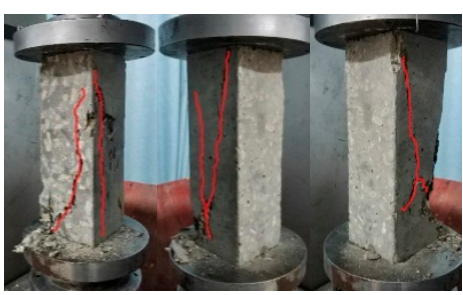

(c)

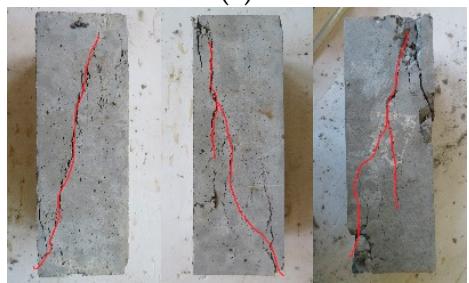

(f)

Figure 4. Typical failure patterns of prism specimens: (a) CAAC-C30; (b) CAAC-C40; (c) CAAC-C50; (d) NAAC-C30; (e) NAAC-C40; and (f) NAAC-C50.

\subsection{Measured Stress-Strain Curve}

Based on the load and displacement of the specimen, the stress-strain curve is plotted in Figure 5. The results show that the shape of the stress-strain curves of CAAC were very similar at different strength grades. From the beginning of loading to $0.60-0.70$ times the peak load, the strain increased almost linearly and the curve began to bend. When the strain reached 0.65-0.70 times the peak strain, the turning point of the strain began to appear. The slope of the convex curve changed little, but, when the stress was close to $0.85-0.90$ times the peak stress $\left(\sigma_{0}\right)$, the slope of the curve changed greatly. It can be seen that, when the stress was greater than $\sigma_{0}$, the stress decreased rapidly, the curve dropped rapidly and the specimen was destroyed quickly and suddenly. This shows that CAAC is brittle and easily damaged when the strain is close to $\sigma_{0}$. Meanwhile, the stress-strain curves of NAAC were similar to the curve of OPC, as shown in Figure 6.

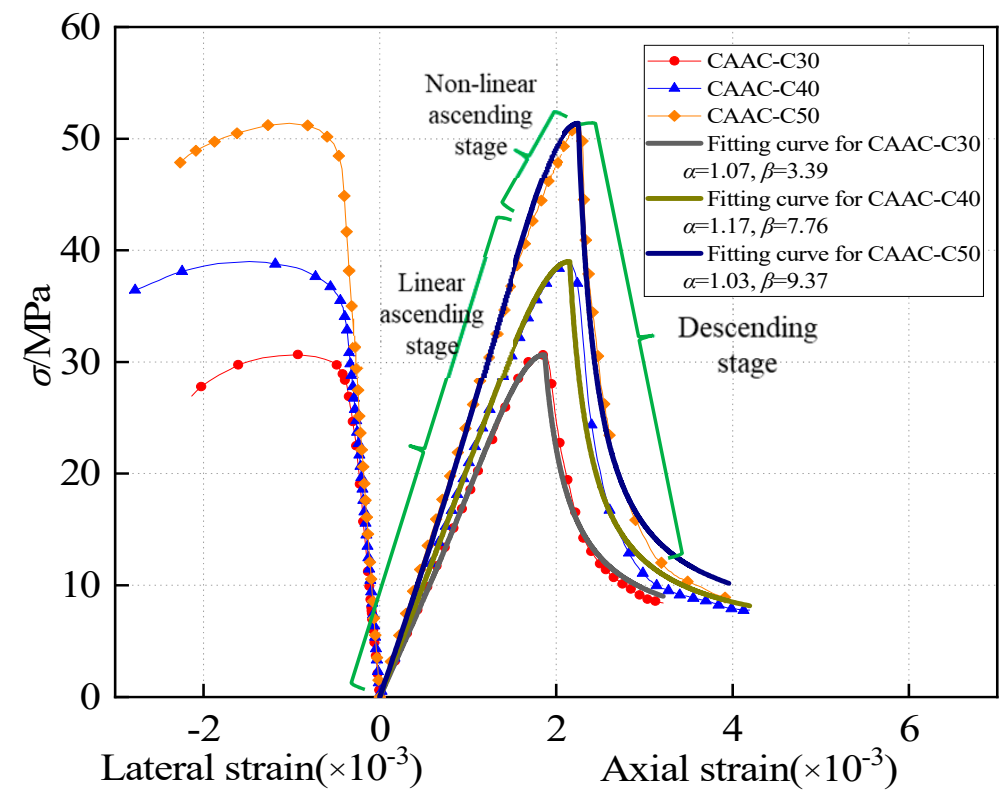

Figure 5. Whole stress-strain curves of CAAC in different strength grades. 


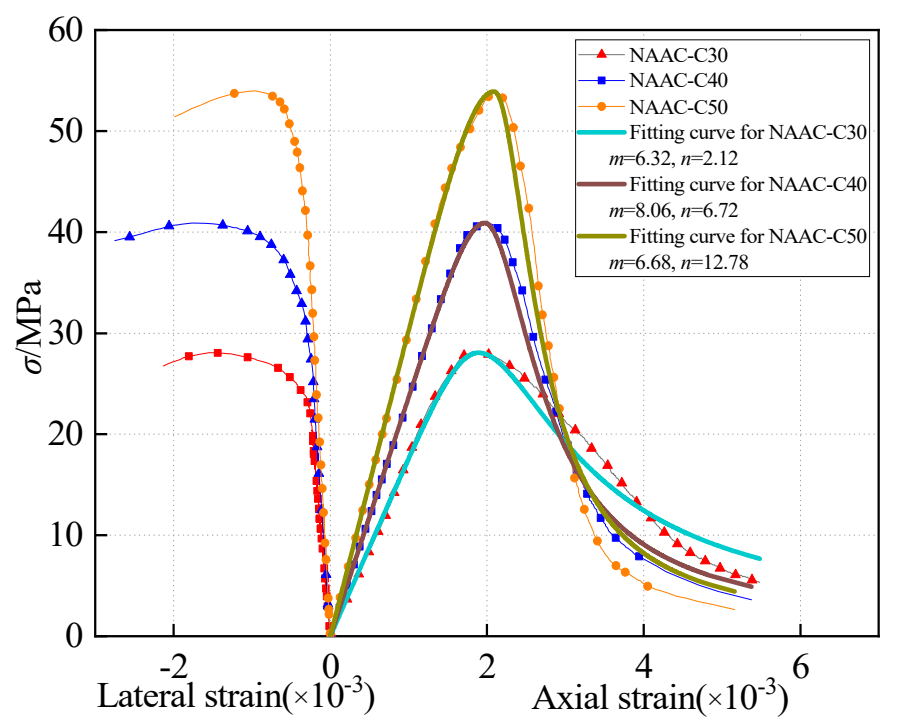

Figure 6. Whole stress-strain curves of NAAC in different strength grades.

\subsection{Mechanical Properties}

The peak stress $\left(\sigma_{0}\right)$, peak strain $\left(\varepsilon_{0}\right)$, residual stress $\left(\sigma_{\mathrm{r}}\right)$ and ultimate strain $\left(\varepsilon_{\mathrm{u}}\right)$ of CAAC and NAAC in three strength grades were measured, as listed in Table 4 . The symbols $\sigma_{0 \mathrm{i}}, \sigma_{\mathrm{ri}}, \varepsilon_{0 \mathrm{i}}$ and $\varepsilon_{\mathrm{ui}}$ represent the mean value of $\sigma_{0}, \sigma_{\mathrm{r}}, \varepsilon_{0}$ and $\varepsilon_{\mathrm{u}}$ of the corresponding concrete specimens, respectively. For CAAC, the value of $\sigma_{\mathrm{ri}} / \sigma_{0 \mathrm{i}}$ was in the range of $0.17-0.28$, decreasing with the increase of strength grade, which may indicate that the damage of CAAC is more serious with the increase of strength grade. The value of $\varepsilon_{\mathrm{u}} / \varepsilon_{0}$ was in the range of 1.72-1.94, which increased at first and then decreased as the strength grade increased. Figure 7 shows the relationship between $\sigma_{0}$ and $\varepsilon_{0}$ of CAAC and NAAC. It can be seen that $\sigma_{0}$ and $\varepsilon_{0}$ tended to increase with the increase of strength grade, which may indicate that the anti-failure ability and safety factor of CAAC and NAAC increase with the increase of strength grade [70].

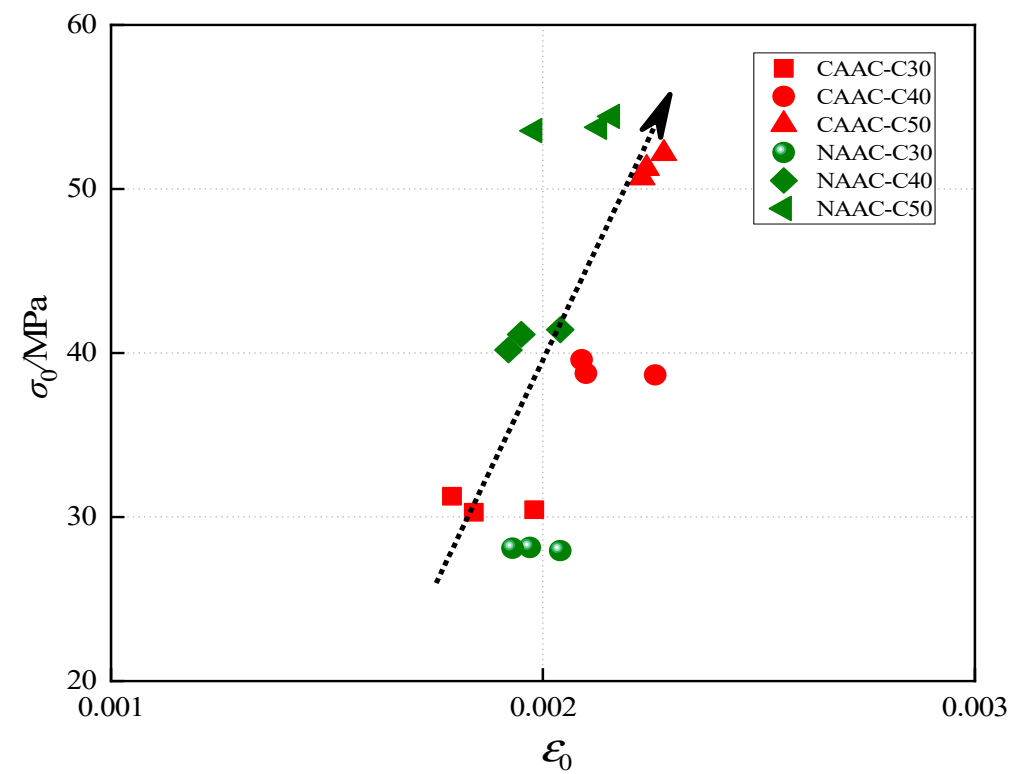

Figure 7. Relationship between peak stress and peak strain of CAAC and NAAC. 
Table 4. Measured mechanical properties of CAAC and NAAC in three strength grades.

\begin{tabular}{|c|c|c|c|c|c|c|c|c|c|c|c|c|c|c|}
\hline No. & $\sigma_{0}$ & $\sigma_{0 \mathrm{i}}$ & $S_{1}$ & $\sigma_{\mathrm{r}}$ & $\sigma_{\mathrm{ri}}$ & $S_{2}$ & $\sigma_{\mathrm{ri}} / \sigma_{0 \mathrm{i}}$ & $\varepsilon_{0}$ & $\varepsilon_{0 \mathrm{i}}$ & $P_{1}$ & $\varepsilon_{\mathbf{u}}$ & $\varepsilon_{\text {ui }}$ & $P_{2}$ & $\varepsilon_{\mathrm{ui}} / \varepsilon_{0 \mathrm{i}}$ \\
\hline \multirow{3}{*}{$\begin{array}{c}\text { CAAC } \\
-30\end{array}$} & 30.29 & \multirow{3}{*}{30.66} & \multirow{3}{*}{0.52} & 8.52 & \multirow{3}{*}{8.41} & \multirow{3}{*}{0.10} & \multirow{3}{*}{0.28} & 0.00184 & \multirow{3}{*}{0.00187} & \multirow{3}{*}{0.00010} & 0.00318 & \multirow{3}{*}{0.00321} & \multirow{3}{*}{0.00006} & \multirow{3}{*}{1.72} \\
\hline & 31.25 & & & 8.38 & & & & 0.00179 & & & 0.00328 & & & \\
\hline & 30.44 & & & 8.33 & & & & 0.00198 & & & 0.00317 & & & \\
\hline \multirow{3}{*}{$\begin{array}{c}\text { CAAC } \\
-40\end{array}$} & 38.75 & \multirow{3}{*}{39.00} & \multirow{3}{*}{0.50} & 7.57 & \multirow{3}{*}{7.76} & \multirow{3}{*}{0.28} & \multirow{3}{*}{0.20} & 0.00210 & \multirow{3}{*}{0.00215} & \multirow{3}{*}{0.00010} & 0.00416 & \multirow{3}{*}{0.00417} & \multirow{3}{*}{0.00005} & \multirow{3}{*}{1.94} \\
\hline & 38.67 & & & 7.63 & & & & 0.00226 & & & 0.00422 & & & \\
\hline & 39.58 & & & 8.08 & & & & 0.00209 & & & 0.00413 & & & \\
\hline \multirow{3}{*}{$\begin{array}{c}\text { CAAC } \\
-50\end{array}$} & 51.25 & \multirow{3}{*}{51.37} & \multirow{3}{*}{0.75} & 8.93 & \multirow{3}{*}{8.89} & \multirow{3}{*}{0.11} & \multirow{3}{*}{0.17} & 0.00224 & \multirow{3}{*}{0.00225} & \multirow{3}{*}{0.00003} & 0.00387 & \multirow{3}{*}{0.0039} & \multirow{3}{*}{0.00007} & \\
\hline & 52.17 & & & 8.76 & & & & 0.00228 & & & 0.00398 & & & 1.76 \\
\hline & 50.69 & & & 8.97 & & & & 0.00223 & & & 0.00400 & & & \\
\hline & 28.14 & & & 5.35 & & & & 0.00197 & & & 0.00542 & & & \\
\hline NAAC & 27.95 & 28.06 & 0.10 & 5.40 & 5.41 & 0.07 & 0.19 & 0.00204 & 0.00198 & 0.00003 & 0.00538 & 0.00537 & 0.00006 & 2.71 \\
\hline-30 & 28.09 & & & 5.48 & & & & 0.00193 & & & 0.00531 & & & \\
\hline & 41.42 & & & 3.69 & & & & 0.00204 & & & 0.00569 & & & \\
\hline NAAC & 40.18 & 40.90 & 0.65 & 3.49 & 3.61 & 0.11 & 0.088 & 0.00203 & 0.00201 & 0.00004 & 0.00579 & 0.00573 & 0.00005 & 2.85 \\
\hline-40 & 41.13 & & & 3.65 & & & & 0.00196 & & & 0.00571 & & & \\
\hline & 54.42 & & & 2.52 & & & & 0.00216 & & & 0.00509 & & & \\
\hline NAAC & 53.76 & 53.91 & 0.45 & 2.64 & 2.63 & 0.11 & 0.049 & 0.00213 & 0.00209 & 0.00010 & 0.00518 & 0.00516 & 0.00006 & 2.46 \\
\hline-50 & 53.55 & & & 2.73 & & & & 0.00198 & & & 0.00521 & & & \\
\hline
\end{tabular}

Note: $\sigma_{0}$ is peak stress, $\sigma_{\mathrm{r}}$ is residual stress, $\varepsilon_{0}$ is peak strain and $\varepsilon_{\mathrm{u}}$ is ultimate strain; $\sigma_{0 \mathrm{i}}, \sigma_{\mathrm{ri}}, \varepsilon_{0 \mathrm{i}}$ and $\varepsilon_{\mathrm{ui}}$ are mean values of $\sigma_{0}, \sigma_{\mathrm{r}}, \varepsilon_{0}$ and $\varepsilon_{\mathrm{u}}$ of the corresponding concrete specimens, respectively; $S_{1}$ and $S_{2}$ are the standard deviations of peak stress and residual stress, respectively; and $P_{1}$ and $P_{2}$ are the standard deviations of peak strain and ultimate strain, respectively. 


\subsection{The Whole Stress-Strain Curve of CAAC}

\subsubsection{Establish the Whole Stress-Strain Curve of CAAC}

As shown in Figure 5, the stress-strain curves of CAAC with different strength grades could be characterized by three stages: linear ascending stage, nonlinear ascending stage and descending stage. The whole stress-strain curve had its own obvious characteristics in the ascending and descending stages, respectively. Different functions were selected to fit the experimental results. By comparing with OPC and LPC, according to the research of Zhen et al. [71], the formula for the ascending stage was as follows:

$$
Y=a x+(5-4 a) x^{4}+(3 a-4) x^{5}(0 \leq x \leq 1)
$$

where $x=\varepsilon / \varepsilon_{0}, \varepsilon$ is the strain, $\varepsilon_{0}$ is the peak strain, $y=\sigma / \sigma_{0}, \sigma$ is the stress, $\sigma_{0}$ is the peak stress and $\alpha$ is the control parameter of ascending stage curve.

Figure 5 shows that, during the descending stage, the decline of CAAC was greater than that of OPC, because CAAC is more brittle than OPC. Therefore, the OPC equation found by Zhenhai et al. [72] in the descending stage is not suitable for CAAC. The descending curve needs to be consistent with the experimental results. The formula for the descending stage was as follows:

$$
Y=\frac{x}{\beta(x-1)+x}(x \geq 1)
$$

where $x=\varepsilon / \varepsilon_{0}, \varepsilon$ is the strain, $\varepsilon_{0}$ is the peak strain, $y=\sigma / \sigma_{0}, \sigma$ is the stress, $\sigma_{0}$ is the peak stress and $\beta$ is the control parameter of descending stage curve.

Because the stress-strain curve of NAAC is similar to that of OPC, the analytical expression of uniaxial compression of OPC in Chinese code GB/T 50010-2010 [73] was used to express the NAAC curve, as shown in Formula (5).

$$
\sigma=\left\{\begin{array}{lr}
\left(\frac{m}{\varepsilon_{0}} \varepsilon+\frac{3-2 m}{\varepsilon_{0}^{2}} \varepsilon^{2}+\frac{m-2}{\varepsilon_{0}^{3}} \varepsilon^{3}\right) f_{\mathrm{C}} & 0 \leq x<1 \\
\frac{f_{\mathrm{c}} \varepsilon}{n \varepsilon_{0}\left(\frac{\varepsilon_{0}}{\varepsilon_{0}}-1\right)^{2}+\varepsilon} & x \geq 1
\end{array}\right.
$$

where $f_{\mathrm{c}}$ is peak stress; $\varepsilon_{0}$ is peak strain; $m$ is a parameter of ascending stage; and $n$ is a parameter of the descending stage.

The normalized whole stress-strain curves of the CAAC in different strength grades is shown in Figure 8, and the curves were similar in the ascending stage. At the same time, the higher the strength grade was, the faster the decline in the descending stage was, the more serious the damage was and the smaller the relative residual stress was [50]. These trends showed that the brittleness of CAAC increased with the increase of strength grade, which was consistent with the performance of OPC. The whole stress-strain curve equation of CAAC with each strength grade has its own related parameters: $\alpha$ and $\beta$ represent the parameters of ascending stage and descending stage, respectively, and $R^{2}$ is the correlation coefficient (Table 5).

Table 5. Relevant parameters of whole stress-strain curve of CAAC at each strength grades.

\begin{tabular}{ccccc}
\hline No. & $\boldsymbol{\alpha}$ & $R_{1}^{2}$ & $\boldsymbol{\beta}$ & $R_{2}^{2}$ \\
\hline CAAC-C30 & 1.07 & 0.998 & 3.39 & 0.958 \\
CAAC-C40 & 1.17 & 0.999 & 7.76 & 0.936 \\
CAAC-C50 & 1.03 & 0.997 & 9.37 & 0.969 \\
\hline
\end{tabular}

Note: $R_{1}^{2}$ is the correlation of parameter $\alpha$ in the ascending stage; $R_{2}^{2}$ is the correlation of parameter $\beta$ in the descending stage; and the closer the value of $R^{2}$ is to 1 , the better are the fitting results. 


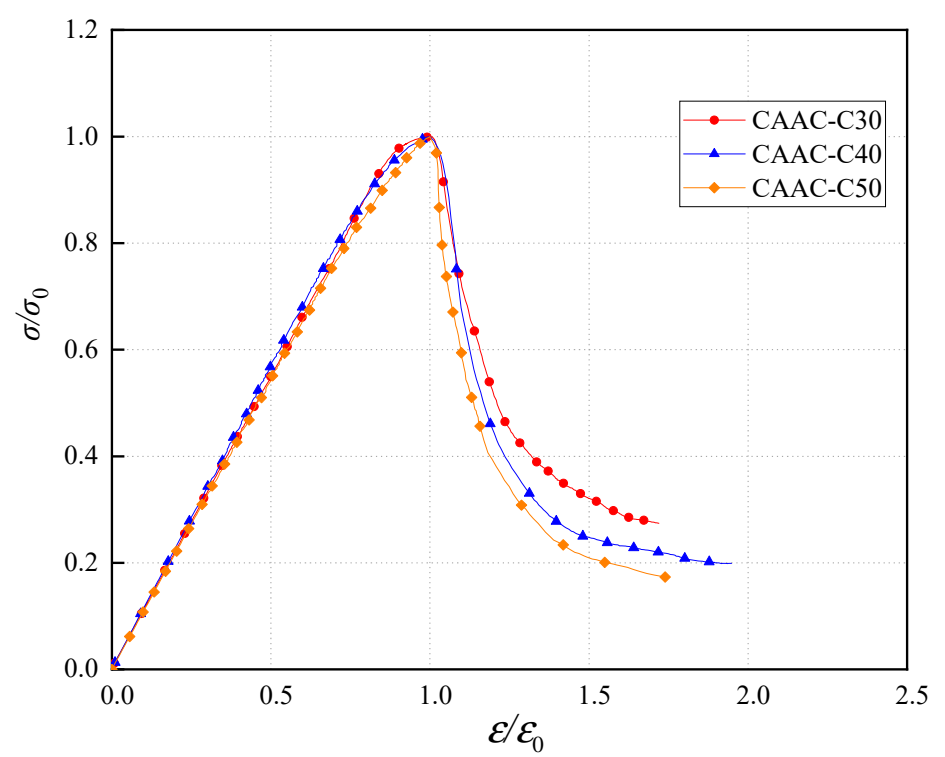

Figure 8. The normalized whole stress-strain curve of CAAC in different strength grades.

\subsubsection{Comparison of Whole Stress-Strain Curve for Different Types of Concrete}

In Figure 9, the whole stress-strain curves of CAAC, NAAC, CPC [70] and LPC [74] are compared. It can be seen that CAAC, NAAC, CPC and LPC showed similar trends in the ascending stage, while there were significant differences in the descending stages. When the strength grade was the same, the descending stage of CAAC was the steepest, which was basically consistent with CPC, indicating that CAAC is more brittle than NAAC and LPC. This further showed that: (a) The strength of corals is lower than that of ordinary stones, volcanic rocks and shales. When the pressure reaches its maximum, the corals will quickly break. (b) The surface of coral is rough and has many pores, which increases the contact area of the interface larger. This is conducive to increasing mechanical interlock and enhancing the combination of coral aggregates and alkali-activated cementing materials [70]. The damage mainly occurs in aggregates and cementing materials, but rarely at the interface. This failure pattern indicates an increase in brittleness of CAAC.

\subsection{Elastic Modulus and Poisson's Ratio of CAAC}

The elastic modulus $\left(E_{c}\right)$ and Poisson's ratio $(\mu)$ of CAAC measured in the test are listed in Table 6 . The results indicate that, when the strength grade increased, $E_{\mathrm{c}}$ increased gradually and $\mu$ increased at first and then decreased. With higher strength grade of CAAC, the relative amount of coral aggregate and the combined surface area of aggregate and cementing material were reduced, which led to the decrease of transverse restraint of concrete and the value of $\mu$ decreased [70].

Table 6. Elastic modulus and Poisson's ratio of CAAC in different strength grades.

\begin{tabular}{ccccc}
\hline No. & $f_{\text {cu }}(\mathbf{M P a})$ & $\left.f_{\mathrm{c}} \mathbf{( M P a}\right)$ & $E_{\mathbf{C}}(\mathbf{G P a})$ & $\mu$ \\
\hline CAAC-C30 & 31.97 & 30.66 & 28.48 & 0.211 \\
CAAC-C40 & 41.96 & 39.00 & 29.56 & 0.232 \\
CAAC-C50 & 55.13 & 51.37 & 31.82 & 0.224 \\
\hline
\end{tabular}

$f_{\text {cu, }}$ cube compressive strength; $f_{\mathrm{c}}$, prism axial compressive strength. 


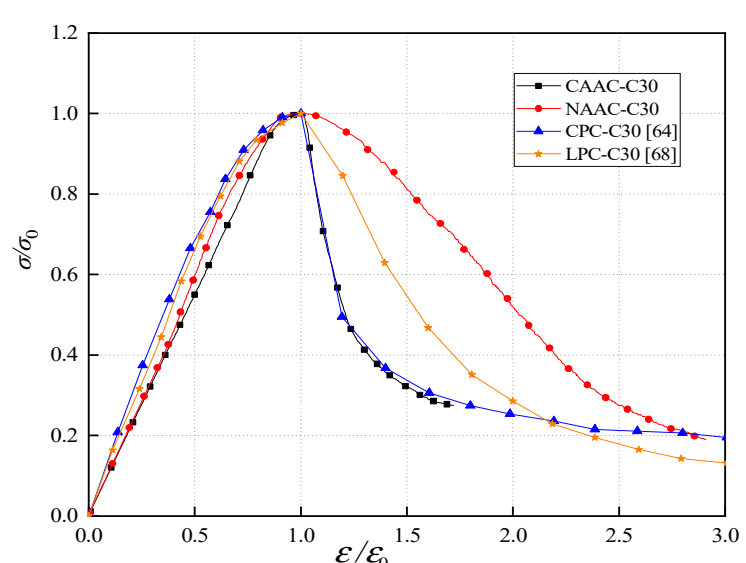

(a)

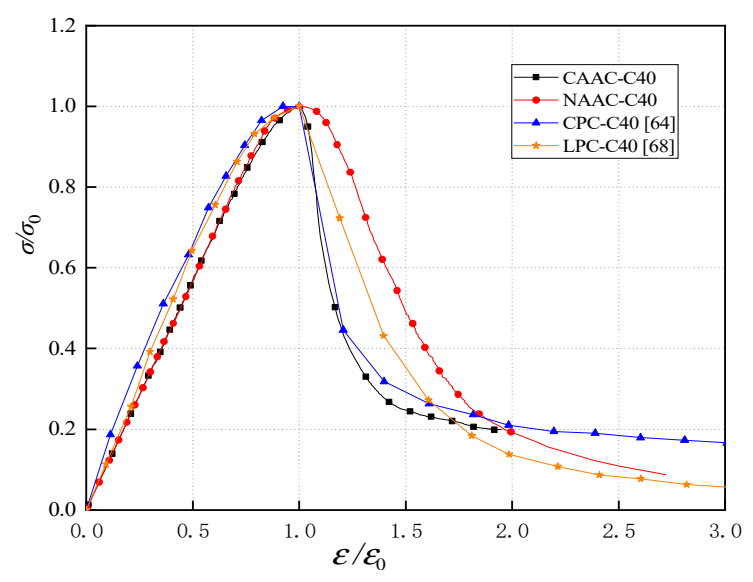

(b)

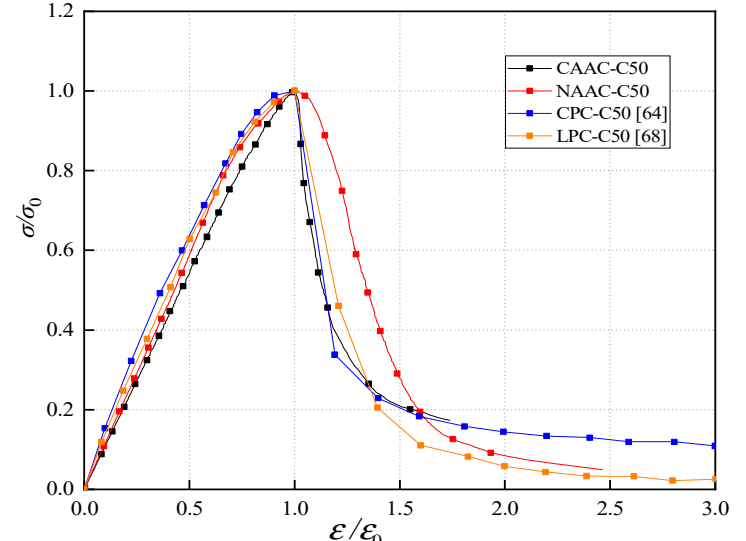

(c)

Figure 9. Comparison of whole stress-strain curve of CAAC, NAAC, CPC and LPC: (a) C30; (b) C40; (c) C50. 
Figure 10 shows the comparison of $E_{\mathrm{c}}$ for CAAC, NAAC, CPC and LPC. The results show that the $E_{\mathrm{C}}$ of CAAC is lower than that of NAAC and CPC, but very close to CPC, and higher than LPC. The $E_{\mathrm{c}}$ of NAAC is the largest. It can be inferred that the type of aggregates has a great influence on $E_{\mathrm{c}}$; the surface characteristics, shape, rigidity and cementing material all have great influence on $E_{\mathrm{c}}$. According to the OPC and LPC in the $E_{\mathrm{c}}$ and $f_{\mathrm{cu}}$ regression formula proposed by Faxing et al. [75], the elastic modulus of CAAC can be predicted by the following formula:

$$
E_{\mathrm{c}}=3.11 \times f_{\mathrm{cu}}^{0.44}
$$

where $E_{\mathrm{c}}$ and $f_{\mathrm{cu}}$ represent elastic modulus (GPa) and cube compressive strength (MPa), respectively.

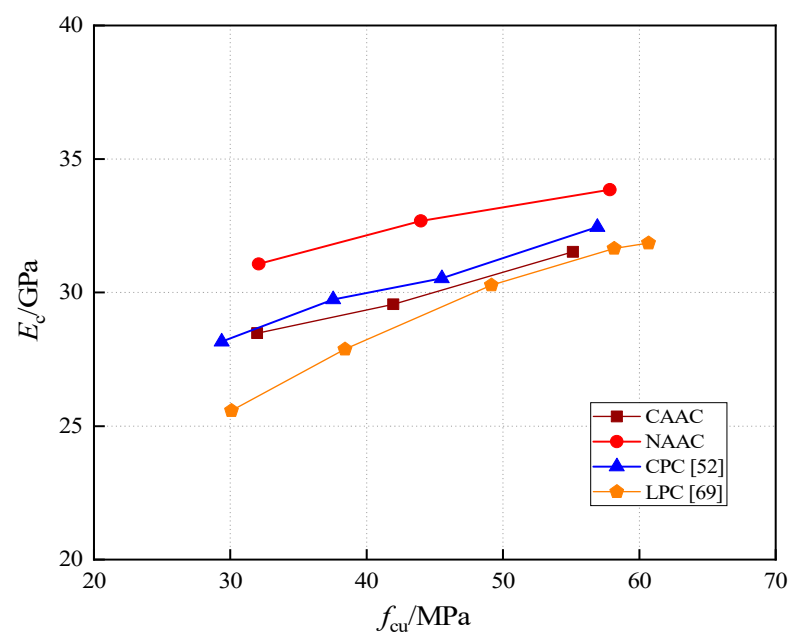

Figure 10. Relationship between $E_{\mathrm{c}}$ and $f_{\mathrm{cu}}$ of CAAC, NAAC, CPC and LPC.

\subsection{Performance Comparison}

The whole stress-strain curve, $E_{\mathrm{c}}$ and $\mu$ of CAAC, NAAC, CPC and LPC were compared and analyzed, and the following results were obtained. When the strength grade is the same, the brittleness order for different types of concrete is as follows: CAAC $>$ CPC $>$ LPC $>$ NAAC. The order of $E_{\mathrm{c}}$ is as follows: NAAC $>$ CAAC $=$ CPC $>$ LPC. The brittleness and elastic modulus of CAAC limit its application in engineering construction. Therefore to expand the application scope of CAAC, it is necessary to improve its strength and toughness. Studies have shown that, to improve the strength of coral, superfine cement mortar and silicon mortar can be added on the surface of coral to form organic or inorganic covering layer to increase the density and rigidity [49]. To prevent CAAC from cracking, organic fiber can be added to CAAC [76]. These measures can produce CAAC with high strength and high toughness.

\subsection{Potential Application of CAAC}

CAAC, which uses coral as coarse aggregates, is similar to CPC in engineering properties and is expected to be applied in engineering construction. Compared with the traditional OPC, CAAC has smaller elastic modulus and larger Poisson's ratio, thus it is suitable for foundations and infrastructures with lower rigidity requirements. Compared with LPC-based concrete, CAAC has similar mechanical properties, and coral can be used to replace some lightweight aggregates. In coastal areas, coral is often treated as waste, and it can be used as aggregates for concrete to save material. In addition, compared with OPC and LPC, CAAC has the greatest brittleness. For some important buildings and structures, this characteristic is often disadvantageous. However, CAAC is recommended for structures such as foundations and walkways, which are subjected to static loads. 


\section{Conclusions}

The whole stress-strain curve of CAAC, which uses geopolymer and coral instead of cement and stone, was compared with NAAC, CPC and LPC. According to the test results, the following conclusions can be obtained:

1. Brittleness is the main cause of CAAC uniaxial compression damage. The CAAC would be divided into multiple cylinders as a splitting failure. The cracks of the specimen are mainly vertical cracks and inclined cracks. In addition, the failure of specimens usually occurs on the slope.

2. According to the whole stress-strain curve of CAAC, the shapes and characteristics vary with different strength grades. As the strength grade increases, the Poisson's ratio $(\mu)$ increases at first and then decreases. The reason is that the bond surface area between coral and cementing material decreases, which leads to the decrease of lateral restraint of concrete.

3. For the whole stress-strain curves of CAAC, NAAC, CPC and LPC, there is no significant difference in the ascending stages, but there is a great difference in the descending stages. At the same strength grade, the descending stage of CAAC is the steepest compared with NAAC and CPC, which is basically consistent with CPC, indicating that CAAC is more brittle than NAAC and LPC. Superfine cement mortar and silicon mortar can be used to increase the strength of coral. It is recommended to add organic fiber to CAAC to improve the strength and toughness.

Author Contributions: Conceptualization, H.W. and B.C.; methodology, L.W., L.L. and B.C.; formal analysis, L.W., L.L. and Y.Z.; investigation, H.W., Y.W. and B.C.; resources, H.W.; data curation, H.W. and B.C.; writing-original draft preparation, H.W., L.W. and Y.W.; writing-review and editing, H.W., L.W., L.L., Y.Z. and B.C.; visualization, H.W. and B.C.; supervision, H.W.; project administration, H.W.; and funding acquisition, H.W. All authors have read and agreed to the published version of the manuscript.

Funding: This project was funded by Guangxi University (Contract No. XGZ160701), National Natural Science Foundation of China (Grant No. 51768003; 51868005) and the Science and Technology Planning Project of GuangXi Province (Grant No. 2017GXNSFAA198360).

Conflicts of Interest: The authors declare that they have no known competing financial interests or personal relationships that could appear to influence the work reported in this paper.

$\begin{array}{ll}\text { Abbreviations } \\ \text { CAAC } & \text { coral fly ash-slag alkali-activated concrete } \\ \text { NAAC } & \text { normal weight alkali-activated concrete } \\ \text { CPC } & \text { coral concrete } \\ \text { OPC } & \text { ordinary concrete } \\ \text { LPC } & \text { lightweight aggregate concrete } \\ \text { AAC } & \text { alkali-activated concrete } \\ \text { FA } & \text { fly ash } \\ \text { GGBFS } & \text { ground granulated blast furnace slag }\end{array}$

\section{References}

1. Malhotra, V.M. Making Concrete "Greener" with Fly Ash-Supplementary Cementing Materials Can Reduce Greenhouse Gas Emissions into the Environment. Concr. Int. 1999, 21, 61-66.

2. Elchalakani, M.; Basarir, H.; Karrech, A. Green Concrete with High-Volume Fly Ash and Slag with Recycled Aggregate and Recycled Water to Build Future Sustainable Cities. J. Mater. Civ. Eng. 2016. [CrossRef]

3. The European Cement Association. Key Facts \& Figures: Global Cement Report. Available online: https://cembureau.eu/cement-101/key-facts-figures/2019 (accessed on 13 July 2019).

4. The Cement Industry Federation (CIF). Federation cement industry, Australian Cement Production. Available online: http://www.cement.org.au (accessed on 25 September 2020). 
5. Hao, J.L.; Cheng, B.; Lu, W.; Xu, J.; Wang, J.; Bu, W.; Guo, Z. Carbon Emission Reduction in Prefabrication Construction during Materialization Stage: A BIM-Based Life-Cycle Assessment Approach. Sci. Total Environ. 2020, 723, 137870. [CrossRef] [PubMed]

6. Cheng, B.; Li, J.; Tam, V.W.; Yang, M.; Chen, D. A BIM-LCA Approach for Estimating the Greenhouse Gas Emissions of Large-Scale Public Buildings: A Case Study. Sustainability 2020, 12, 685. [CrossRef]

7. Chen, H.; Li, H.; Wang, Y.; Cheng, B. A Comprehensive Assessment Approach for Water-Soil Environmental Risk during Railway Construction in Ecological Fragile Region Based on AHP and MEA. Sustainability 2020, 12, 7910. [CrossRef]

8. Hardjito, D.; Wallah, S.E.; Rangan, B.V. Study on Engineering Properties of Fly Ash-Based Geopolymer Concrete. J. Australas. Ceram. Soc. 2002, 38, 44-47.

9. Huntzinger, D.N.; Eatmon, T.D. A Life-Cycle Assessment of Portland cement Manufacturing: Comparing the Traditional Process with Alternative Technologies. J. Clean. Prod. 2009, 17, 668-675. [CrossRef]

10. Yuan, H.; Shen, L. Trend of the Research on Construction and Demolition Waste Management. Waste Manag. 2011, 31, 670-679. [CrossRef]

11. Chen, J.; Hua, C.; Liu, C. Considerations for Better Construction and Demolition Waste Management: Identifying the Decision Behaviors of Contractors and Government Departments through a Game Theory Decision-Making Model. J. Clean. Prod. 2019, 212, 190-199. [CrossRef]

12. Xiao, J.; Li, W.; Fan, Y.; Huang, X. An Overview of Study on Recycled Aggregate Concrete in China (1996-2011). Constr. Build. Mater. 2012, 31, 364-383. [CrossRef]

13. Tam, V.W.Y.; Soomro, M.; Jorge Evangelista, A.C. A Review of Recycled Aggregate in Concrete Applications (2000-2017). Constr. Build. Mater. 2011, 72, 272-292. [CrossRef]

14. Luo, Z.; Li, W.; Tam, V.W.; Xiao, J.; Shah, S.P. Current progress on nanotechnology application in recycled aggregate concrete. J. Sustain. Cem. Mater. 2018, 8, 1-18. [CrossRef]

15. Nour, A.I.; Güneyisi, E.M. Prediction Model on Compressive Strength of Recycled Aggregate Concrete Filled Steel Tube Columns. Compos. Part B Eng. 2019, 173, 106938. [CrossRef]

16. Shi, X.; Collins, F.; Zhao, X.; Wang, Q. Mechanical Properties and Microstructure Analysis of fly Ash Geopolymeric Recycled Concrete. J. Hazard. Mater. 2012, 237, 20-29. [CrossRef] [PubMed]

17. Li, N.; Shi, C.; Zhang, Z.; Wang, H.; Liu, Y. A Review on Mixture Design Methods for Geopolymer Concrete. Compos. Part B Eng. 2019, 178, 107490. [CrossRef]

18. Longhi, M.A.; Walkley, B.; Rodríguez, E.D.; Kirchheim, A.P.; Zhang, Z.; Wang, H. New Selective Dissolution Process to Quantify Reaction Extent and Product Stability in Metakaolin-Based Geopolymers. Compos. Part B Eng. 2019, 176, 107172. [CrossRef]

19. Khodr, M.; Law, D.W.; Gunasekara, C.; Setunge, S.; Brkljaca, R. Compressive Strength and Microstructure Evolution of Low Calcium Brown Coal Fly Ash-Based Geopolymer. J. Sustain. Cem. Mater. 2019, 9, 17-34. [CrossRef]

20. Koushkbaghi, M.; Alipour, P.; Tahmouresi, B.; Mohseni, E.; Saradar, A.; Sarker, P.K. Influence of Different Monomer Ratios and Recycled Concrete Aggregate on Mechanical Properties and Durability of Geopolymer Concretes. Constr. Build. Mater. 2019, 205, 519-528. [CrossRef]

21. Posi, P.; Teerachanwit, C.; Tanutong, C.; Limkamoltip, S.; Chindaprasirt, P. Lightweight Geopolymer Concrete Containing Aggregate from Recycle Lightweight Block. Mater. Des. 2013, 52, 580-586. [CrossRef]

22. Nuaklong, P.; Sata, V.; Chindaprasirt, P. Influence of Recycled Aggregate on Fly Ash Geopolymer Concrete Properties. J. Clean. Prod. 2016, 112, 2300-2307. [CrossRef]

23. Davidovits, J. High-Alkali Cements for 21st Century Concretes. ACI 1994, 144, 383-398. [CrossRef]

24. Li, Z.; Ding, Z.; Zhang, Y. Development of Sustainable Cementitious Materials. In Proceedings of the International Workshop on Sustainable Development and Concrete Technology, Beijing, China, 20-21 May 2004; pp. 55-76. Available online: http://publications.iowa.gov/2941/1/SustainableConcreteWorkshop.pdf\#page=66 (accessed on 25 September 2020).

25. Duxson, P.; Provis, J.L.; Lukey, G.C.; Deventer, J.S.J.V. The Role of Inorganic Polymer Technology in the Development of 'Green Concrete'. Cem. Concr. Res. 2007, 37, 1590-1597. [CrossRef]

26. Dong, M.; Feng, W.; Elchalakani, M.; Li, G.; Karrech, A.; May, E.F. Development of a High Strength Geopolymer by Novel Solar Curing. Ceram. Int. 2017, 43, 11233-11243. [CrossRef] 
27. Elchalakani, M.; Dong, M.; Karrech, A.; Li, G.; Ali, M.S.M.; Xie, T. Development of Fly-Ash and Slag-Based Geopolymer Concrete with Calcium Carbonate or Microsilica. J. Mater. Civ. Eng. 2018, 30, 04018325.1-04018325.14. [CrossRef]

28. Atis, C.D.; Gorur, E.B.; Karahan, O.; Bilim, C.; Ilkentapar, S.; Luga, E. Very High Strength (120 MPa) Class F Fly Ash Geopolymer Mortar Activated at Different $\mathrm{NaOH}$ Amount, Heat Curing Temperature and Heat Curing Duration. Constr. Build. Mater. 2015, 96, 673-678. [CrossRef]

29. Hosan, A.; Haque, S.; Shaikh, F. Compressive Behaviour of Sodium and Potassium Activators Synthetized Fly Ash Geopolymer at Elevated Temperatures: A Comparative Study. J. Build. Eng. 2016, 8, 123-130. [CrossRef]

30. Pan, Z.; Sanjayan, J.G. Stress-Strain Behaviour and Abrupt Loss of Stiffness of Geopolymer at Elevated Temperatures. Cem. Concr. Compos. 2010, 32, 657-664. [CrossRef]

31. Bernal, S.A.; De Gutierrez, R.M.; Provis, J.L.; Rose, V. Effect of Silicate Modulus and Metakaolin Incorporation on the Carbonation of Alkali Silicate-Activated Slags. Cem. Concr. Res. 2010, 40, 898-907. [CrossRef]

32. Bernal, S.A.; Gutierrez, R.M.D.; Provis, J.L. Engineering and Durability Properties of Concretes Based on Alkali-Activated Granulated Blast Furnace Slag/Metakaolin Blends. Constr. Build. Mater. 2012, 33, $99-108$. [CrossRef]

33. Monticelli, C.; Natali, M.E.; Balbo, A.; Chiavari, C.; Bignozzi, M.C. Corrosion Behavior of Steel in Alkali-Activated Fly Ash Mortars in the Light of Their Microstructural, Mechanical and Chemical Characterization. Cem. Concr. Res. 2016, 80, 60-68. [CrossRef]

34. Babaee, M.; Castel, A. Chloride-Induced Corrosion of Reinforcement in Low-Calcium Fly Ash-Based Geopolymer Concrete. Cem. Concr. Res. 2016, 88, 96-107. [CrossRef]

35. Fernández-Jiménez, A.; Lodeiro, I.G.; Palomo, A. Durability of Alkali-Activated Fly Ash Cementitious Materials. J. Mater. Sci. 2006, 42, 3055-3065. [CrossRef]

36. Castel, A.; Foster, S.J. Bond Strength between Blended Slag and Class F Fly Ash Geopolymer Concrete with Steel Reinforcement. Cem. Concr. Res. 2015, 72, 48-53. [CrossRef]

37. Kim, J.S.; Park, J. An Experimental Evaluation of Development Length of Reinforcements Embedded in Geopolymer Concrete. Appl. Mech. Mater. 2014, 578, 441-444. [CrossRef]

38. Moser, R.D.; Allison, P.G.; Williams, B.; Weiss, C.; Diaz, A.; Gore, E.; Malone, P. Improvement in the Geopolymer-To-Steel Bond Using A Reactive Vitreous Enamel Coating. Constr. Build. Mater. 2013, 49, 62-69. [CrossRef]

39. Ganesan, N.; Indira, P.V.; Santhakumar, A. Bond Behaviour of Reinforcing Bars Embedded in Steel Fibre Reinforced Geopolymer Concrete. Mag. Concr. Res. 2014, 67, 9-16. [CrossRef]

40. Dattatreya, J.K.; Rajamane, N.P.; Sabitha, D.; Ambily, P.S.; Nataraja, M.C. Flexural Behaviour of Reinforced Geopolymer Concrete Beams. Int. J. Compu. Civ. Struct. Eng. 2012, 2, 138-159.

41. Yost, J.R.; Radlinska, A.; Ernst, S.; Salera, M.; Martignetti, N.J. Structural Behavior of alkali activated fly ash concrete. Part 2: Structural Testing and Experimental Findings. Mater. Struct. 2013, 46, 449-462. [CrossRef]

42. Nguyen, K.T.; Le, T.A.; Lee, K. Experimental Study on Flexural Strength of Reinforced Geopolymer Concrete Beams. Int. J. Civ. Environ. Eng. 2016, 10, 4.

43. Cui, Y.; Gao, K.; Zhang, P. Experimental and Statistical Study on Mechanical Characteristics of Geopolymer Concrete. Materials 2020, 13, 1651. [CrossRef]

44. Risdanareni, P.; Zaccardi, Y.V.; Schollbach, K.; Wang, J.; Belie, N.D. Properties of Alkali Activated Lightweight Aggregate Generated from Sidoarjo Volcanic Mud (Lusi), Fly Ash, and Municipal Solid Waste Incineration Bottom Ash. Materials 2020, 13, 2528. [CrossRef] [PubMed]

45. Giergiczny, Z. Fly Ash and Slag. Cem. Concr. Res. 2019, 124, 105826. [CrossRef]

46. Longo, F.; Cascardi, A.; Lassandro, P.; Aiello, M.A. A New Fabric Reinforced Geopolymer Mortar (FRGM) with Mechanical and Energy Benefits. Fibers 2020, 8, 49. [CrossRef]

47. Wang, H.; Wu, Y.; Wei, M.; Wang, L.; Cheng, B. Hysteretic Behavior of Geopolymer Concrete with Active Confinement Subjected to Monotonic and Cyclic Axial Compression: An Experimental Study. Materials 2020, 13, 3997. [CrossRef]

48. Nowoświat, A.; Golaszewski, J. Influence of the Variability of Calcareous Fly Ash Properties on Rheological Properties of Fresh Mortar with Its Addition. Materials 2019, 12, 1942. [CrossRef] 
49. Cevik, A.; Alzeebaree, R.; Humur, G.; Nis, A.; Gülşan, M.E. Effect of Nano-Silica on the Chemical Durability and Mechanical Performance of Fly Ash Based Geopolymer Concrete. Ceram. Int. 2018, 44, 12253-12264. [CrossRef]

50. Li, L. Research on Basic Characteristics of Coral Concrete; Guangxi University: Nanning, China, 2012.

51. Zhang, S.Z. Experimental Study on the Fatigue Property and Microscopic Mechanism of Coral Concrete; Guangxi University: Nanning, China, 2012.

52. Dempsey, G. Coral and Salt Water as Concrete Materials. ACI Mater. 1951, 48, 157-166.

53. Vines, F.R. Experience with Use of Coral Detritus as Concrete Aggregate in Western Samoa. Aust. Road Res. $1982,12,17-28$.

54. Chen, Z.L.; Chen, T.Y.; Qu, Z.M. A Feasibility Study of Application of Coral Reef Sand Concrete. Ocean Eng. 1991, 9, 67-80.

55. Chen, Z.L.; Sun, G.F.; Tang, X.N. Study on Applications of Concretes from Coral Reef Sand Mixed with Seawater for Patching-Up in Reef Engineering. Coast. Eng. 2008, 27, 60-69.

56. Wang, L.; Zhao, Y.L. The Comparison of Coral Concrete and Other Light Weight Aggregate Concrete on Mechanics Performance. Adv. Mater. Res. 2012, 446, 3369-3372. [CrossRef]

57. Li, Y.T.; Zhou, L.; Zhang, Y.; Cui, J.W.; Shao, J. Study on Long-Term Performance of Concrete Based on Seawater, Sea Sand and Coral Sand. Adv. Mater. Res. 2013, 706-708, 512-515. [CrossRef]

58. Kong, L.J.; Ge, Y.; Yuan, J.; Zhang, B.S. Stress-Strain Curves of Combined Aggregate Concrete. J. Wuhan Univ. Technol. 2007, 29, 18-21.

59. Petersen, L.; Lohaus, L.; Polak, M.A. Influence of Freezing-and-Thawing Damage on Behavior of Reinforced Concrete Elements. ACI Mater. J. 2007, 104, 369-378.

60. Hasan, M.; Ueda, T.; Sato, Y. Stress-Strain Relationship of Frost-Damaged Concrete Subjected to Fatigue Loading. J. Mater. Civ. Eng. 2008, 20, 37-45. [CrossRef]

61. Wu, Q.; Zhang, H.; Jia, X.; Chen, H.; Yu, W. Experimental Investigation of Stress-Strain Curves of Cast-In-Situ Phosphogypsum. J. Build. Struct. 2015. [CrossRef]

62. China MOCO. Light Aggregate and Test Method; China Architecture\& Building Press: Beijing, China, 1998.

63. Vora, P.R.; Dave, U.V. Parametric Studies on Compressive Strength of Geopolymer Concrete. Procedia Eng. 2013, 51, 210-219. [CrossRef]

64. Yuan, Y.F. Mix Design and Property of Coral Aggregate Concrete; Nanjing University of Aeronautics and Astronautics: Nanjing, China, 2015.

65. China MOCO. Standard for Test Method of Mechanical Properties on Ordinary Concrete; China Architecture\& Building Press: Beijing, China, 2002.

66. Wang, Z.; Li, L.; Zhang, Y. Bond-Slip Model Considering Freeze-Thaw Damage Effect of Concrete and Its Application. Eng. Struct. 2019, 201, 109831. [CrossRef]

67. Wang, Z.; Li, L.; Zhang, Y. Reinforcement Model Considering Slip Effect. Eng. Struct. 2019, 198, 109493. [CrossRef]

68. Shi, G.; Cheng, B.; Li, A. A Mathematical Model for Calculating the "Brittleness-Ductility" Drop Coefficient of Sandstone in Mining Zones. Discrete Dyn. Nat. Soc. 2020, 2020, 2621672. [CrossRef]

69. Chen, G.M.; Yang, H.; Lin, C.J.; Chen, J.F.; He, Y.H.; Zhang, H.Z. Fracture Behaviour of Steel Fibre Reinforced Recycled Aggregate Concrete after Exposure to Elevated Temperatures. Constr. Build. Mater. 2016, 128, 272-286. [CrossRef]

70. Da, B.; Yu, H.; Ma, H.; Tan, Y.; Mi, R.; Dou, X. Experimental Investigation of Whole Stress-Strain Curves of Coral Concrete. Constr. Build. Mater. 2016, 122, 81-89. [CrossRef]

71. Zheng, W.; Li, H.; Wang, Y. Compressive Stress-Strain Relationship of Steel Fiber-Reinforced Reactive Powder Concrete after Exposure to Elevated Temperatures. Constr. Build. Mater. 2012, 35, 931-940. [CrossRef]

72. Guo, Z. Strength and Constitutive Relationship of Concrete-Principle and Application; China Building Industry Press: Beijing, China, 2004.

73. China MOCO. Code for Design of Concrete Structures; China Architecture\& Building Press: Beijing, China, 2010.

74. Wang, Z.Y.; Ding, J.T.; Guo, Y.S. Stress-Strain Curves of Structural Lightweight Aggregate Concretes. Concretes 2005, 27, 39-41. 
75. Ding, F.X.; Ying, X.Y.; Yu, Z.W. Unified Calculation Method of Uniaxial Mechanical Properties of Lightweight Aggregate Concrete. J. Cent. South Univ. Sci. Technol. 2010, 41, 1973-1979.

76. Niu, D.; Su, L.; Luo, Y.; Huang, D.; Luo, D. Experimental Study on Mechanical Properties and Durability of Basalt Fiber Reinforced Coral Aggregate Concrete. Constr. Build. Mater. 2020, 237, 117628. [CrossRef]

(C) 2020 by the authors. Licensee MDPI, Basel, Switzerland. This article is an open access article distributed under the terms and conditions of the Creative Commons Attribution (CC BY) license (http://creativecommons.org/licenses/by/4.0/). 